\title{
A Ruptura do Nexo de Causalidade Diante da Contaminação pelo Vírus da COVID-19 em Vítimas de Disparos de Arma de Fogo
}

\author{
The Rupture of the Causal Link in the Contamination by Covid-19 Viruses in Firearms \\ Shooting Victims
}

\author{
Luan Paixão Rampinelli
}

Universidade Estadual de Londrina, Pós-Graduação em Direito Penal e Processo Penal. PR, Brasil.

E-mail: luanpaixao@hotmail.com

\begin{abstract}
Resumo
O trabalho em epígrafe busca a análise detida da ocorrência ou não da ruptura do nexo de causalidade em morte decorrente de contaminação pelo vírus da COVID-19 em casos de vítimas de disparos de arma de fogo. Trata-se de estudo de notável importância para a seara do Direito Penal, uma vez ser notória a existência de debates sobre a existência do nexo de causalidade em casos específicos. Partindo-se deste pressuposto se torna imperiosa a interpretação, ainda que de forma crítica, das teorias adotadas pelo Código Penal sobre o nexo causal, perquirindo se a regra ou se a exceção deve ser adotada na situação fática ora analisada. O estudo, para tanto, analisa as interpretações doutrinárias e jurisprudenciais em hipóteses semelhantes sobre o nexo de causalidade em vítimas de disparos de arma de fogo. Por fim, concluída a análise das questões mencionadas se tornou inconteste a necessidade de se aferir, na hipótese em tela, se há ou não a ruptura do nexo de causalidade, interferindo na própria tipificação do delito, seja na modalidade consumada, seja na modalidade tentada a depender da ruptura ou não do nexo causal.
\end{abstract}

Palavras-chave: Nexo Causal. COVID-19. Concausas.

\begin{abstract}
This study aims to analyze the occurrence or not of the rupture of the causal link in death from contamination by the virus of COVID-19 in cases of firearm shots victims. This is a study of notable importance in criminal law, since there are notorious debates about the existence of a causal link in specific cases. Based on this assumption, it is imperative to analyze, albeit in a critical way, the theories adopted by the criminal law on the causal link, investigating whether the rule or the exception should be adopted in the factual situation here analyzed. The study, therefore, analyzes the doctrinal and jurisprudential interpretations in similar hypotheses about the causal link in firearm shots victims. Finally, after the analysis of the aforementioned issues was completed, the need to assess, in the hypothesis, whether or not there is a rupture of the causal link, interfering in the classification of the crime, whether in the consummated or in the attempted modality, to depend on the rupture or not of the causal nexus.
\end{abstract}

Keywords: Causal Link. COVID-1.; Concauses.

\section{Introdução}

A Pandemia da COVID-19 que, infelizmente, assola a todos desde 2020, fez surgir interessantes debates jurídicos em decorrência das situações fáticas geradas pela excepcional realidade surgida.

Um dos debates que possui relevância prática é a ruptura, ou não, do nexo de causalidade em casos nos quais uma vítima de disparo de arma de fogo, hospitalizada, é contaminada pelo vírus e vai a óbito.

O presente artigo, portanto, tem como premissa básica a análise específica das teorias adotadas pelo Código Penal quanto ao nexo de causalidade, suas concausas e demais avenças pertinentes, sendo que, após se analisará, especificamente, a situação fática envolvendo o homicídio de vítima de disparos de arma de fogo que, ao ser internada após ser alvejada, contrai o vírus da COVID-19 e, infelizmente, falece.

O grande debate que exsurge diz respeito à previsibilidade, ou não, da contaminação pelo vírus da COVID-19 quando do disparo de arma de fogo pelo agente infrator, isto é, se a contaminação se encontra no desdobramento natural do evento ou se, per si, culminou no resultado morte.

A depender da resposta ao questionamento alhures se poderá estar diante de um crime na modalidade consumada ou, ainda, na modalidade tentada, tornando-se imperiosa a análise do fato de a contaminação ser, ou não, causa suficiente e autônoma do evento morte.

Presume-se, portanto, que a relevância do presente debate recai, mais profusamente, na tipificação do delito, podendo restar configurada a modalidade consumada ou a modalidade tentada do delito (configurando, portanto, circunstância minorante de pena na terceira fase da dosimetria).

O objetivo do presente artigo, portanto, é claro: analisar se eventual contaminação pelo vírus da COVID-19 por vítima de disparos de arma de fogo estaria, ou não, no desdobramento natural do evento, perquirindo qual teoria do ordenamento 
jurídico pátrio deveria ser adotada, ou seja, conditio sine qua non (teoria da equivalência dos antecedentes) ou, por outro norte, teoria da causalidade adequada.

\section{Desenvolvimento}

\subsection{Metodologia}

De início, é imperioso que se ressalte que a metodologia utilizada para o presente trabalho ocorreu, de forma exploratória, através da análise do ordenamento jurídico pátrio, da doutrina, por meio de revisão bibliográfica, e da jurisprudência preponderante no País, eis que se trata de um tema que é de relevância tanto para o Poder Legislativo (teorias adotadas pelo Código Penal) quanto para o Poder Judiciário.

\subsection{Das teorias adotadas pelo Código Penal e suas aplicações práticas na hipótese de contaminação pelo vírus da COVID-19 em vítima de disparos de arma de fogo}

Ao tratar do nexo de causalidade, o ordenamento jurídico pátrio adotou a Teoria da Equivalência dos Antecedentes Causais (conditio sine qua non), prevista no art. 13, caput, do Código Penal, segundo a qual todo evento provocado pelo agente, que possua relevância causal para o resultado, deverá ser considerado como "causa".

Trata-se de uma teoria igualitária, visto que, como o próprio nome destaca, todos os acontecimentos antecedentes concorrem como a causa do evento, sendo assim considerados aqueles que evidenciam relevância, importância, para o advento do resultado.

A questão proposta se encontra no campo das concausas, previstas no art. $13, \S 1^{\circ}$, do Código Penal quando diz que "a superveniência de causa relativamente independente exclui a imputação quando, por si só, produziu o resultado. Os fatos anteriores, entretanto, se imputam a quem os praticou" (Código Penal). Trata-se de exceção, com a adoção de uma teoria diferenciadora, a da Teoria da Causalidade Adequada.

Apenas para uma análise geral sobre o tema se tem que as concausas se subdividem em preexistentes, concomitantes ou supervenientes, podendo, ainda, ser dependentes e absoluta ou relativamente independentes do comportamento do agente.

Sendo dependente se insere na linha natural de desdobramento da conduta do agente infrator, tratando-se de consequência esperada, "como ocorre no caso da morte por choque hemorrágico subsequente a um ferimento perfurante profundo" (ESTEFAM; GONÇALVES, 2020, p.458).

Por outro norte, quanto à concausa independente (que produz, per si, o resultado danoso, sendo fator não esperado), há uma subdivisão entre absoluta ou relativamente independente.

Sendo absolutamente independente (preexistente, concomitante ou superveniente), o resultado danoso não poderá ser imputado ao agente infrator, visto que ocorreria independentemente de sua conduta.
Apenas exemplificando se tem o caso de uma vítima hipotética que foi envenenada e, de forma absolutamente independente, é alvejada por disparos de arma de fogo por outro desafeto (fator superveniente), falecendo em decorrência destes ferimentos e não pelo envenenamento. $\mathrm{O}$ agente infrator (quem envenenou) responderia, apenas, pela forma tentada do delito.

No caso da concausa relativamente independente, não haverá de se falar na ruptura do nexo de causalidade entre a conduta do agente e o resultado danoso. A concausa se une à conduta e, diante da referida união/combinação, advém o resultado. O agente responderia, portanto, pela forma consumada do delito (exemplo clássico dado pela doutrina é a vítima hemofílica atingida por golpes de instrumento cortante e que "sangra até sua morte" - concausa preexistente).

Ocorre que, ao se analisar a concausa superveniente (surgida após a conduta do agente) relativamente independente se tem que esta pode ou não ser suficiente para romper o nexo causal e produzir, per si, o resultado.

Caso não produza, por si só, o resultado, o agente infrator responderá pelo delito na forma consumada (adotandose a regra do Código Penal, sendo que sua conduta será considerada causa). Caso produza o resultado per si, o agente responderá apenas pelos atos anteriores (com esteio na exceção da causalidade adequada - sua conduta não terá alcançado o fim desejado, visto que decorreu da causa superveniente), pois "nessa situação, entende o legislador que há imprevisibilidade, motivo pelo qual o nexo causal pode ser cortado" (NUCCI, 2020, p.284).

Casos como infecção hospitalar ou erros médicos são tidos, pela doutrina majoritária, como causas supervenientes relativamente independentes que não são capazes de, isoladamente, produzirem o resultado, pois estariam na linha de desdobramento natural do evento. O agente responderia, portanto, pelo crime consumado.

Na situação proposta, em um contexto de Pandemia se questiona: a contaminação é capaz de produzir o resultado morte ou faz parte do desdobramento causal da conduta anterior (disparo de arma de fogo)?

Aqui surge a nuclear relevância de ambas as teorias tratadas anteriormente sobre o nexo causal, visto que o Código Penal define em qual situação deve incidir a regra geral (conditio sine qua non) e qual deve ser regulada pela exceção (causalidade adequada).

Diante do panorama apresentado, a questão jurídica que se exsurge é simples: a contaminação pelo vírus da COVID-19 estaria, nas palavras de Guilherme de Souza Nucci, na "linha evolutiva do perigo" (NUCCI, 2019, p.136) do evento fático ocorrido?

Imagine-se uma situação em que o agente realiza disparos de arma de fogo em direção à determinada pessoa, alvejando-a. Ao ser transportada para o hospital mais próximo e, como infelizmente ocorre, na grande maioria das instituições 
hospitalares, atualmente, se encontra com superlotação em decorrência da Pandemia da COVID-19. Em que pese tenham sido tomadas as medidas possíveis, a vítima é contaminada pelo vírus e falece.

Referida contaminação seria suficiente para romper o nexo causal e produzir, per si, o resultado morte? Por se estar analisando uma concausa relativamente independente, é óbvio que não se pode afastar a relevância/relação dessa para a conduta do agente. Todavia, o que se deverá aferir é se o resultado morte teve a efetiva contribuição do disparo de arma de fogo ou se foi causada, exclusivamente, pela contaminação (COVID-19), com ruptura do nexo causal em relação aos disparos.

Para se quebrar o nexo "é preciso que a concausa saia da cadeia de desdobramento normal da causa originária" (STJ - AgRg no REsp 1678232/SE, QUINTA TURMA, julgado em 24/10/2017, DJe 31/10/2017). No tocante ao vírus da COVID-19, ao menos aparentemente e seguindo as lições da doutrina majoritária, é possível concluir que este possui força suficiente para romper com o nexo causal e, por si só, causar o resultado morte.

Ora, diferentemente do caso de eventual imperícia médica, em que a cirurgia decorreu necessariamente dos disparos não fatais, não se pode concluir que a contaminação da vítima pelo vírus da COVID-19 tenha decorrido única e exclusivamente da empreitada delituosa.

Explica-se: em caso de imperícia médica ou, ainda, infecção hospitalar nas lesões decorrentes dos disparos de arma de fogo, estas são a causa da morte, contando com o acréscimo de uma concausa relativamente independente que somente contribui para o resultado morte. Há uma soma entre a conduta do agente e a concausa para que se chegasse ao resultado. Como explica a doutrina, "suprimindo-se o ferimento, a morte teria ocorrido? Não, pois sem ferimento não haveria o que infeccionar. Logo, podemos estabelecer uma relação entre a conduta anterior e o evento posterior" (BITENCOURT, 2020, p.726).

Ser a vítima contaminada pelo vírus não é um resultado normal e previsível, quando da perpetração da conduta delitiva (disparos de arma de fogo). Não há como se concluir, ainda que se análise a incontestável e infeliz gravidade da situação fática dos hospitais do País, que uma vítima de disparo de arma de fogo necessariamente será contaminada pelo vírus e, em razão disso, falecerá. Não há uma soma de fatores (concausa e a conduta do agente), justamente pela anormalidade do evento superveniente aos disparos.

Aqui não parece ser possível a adoção de uma teoria igualitária, considerando-se a conduta do agente como causa suficiente da morte. Ao contrário: o caso concreto demanda a utilização da exceção trazida pelo Código Penal, a Teoria da Causalidade Adequada, cuja aplicação conduz à conclusão de que a contaminação foi a causa efetiva do resultado morte.

A vítima, mesmo que socorrida em hospital que encontra elevado número de pacientes contaminados, não necessariamente, será contaminada (ao menos em regra). E mais, ainda que seja contaminada, não necessariamente falecerá em decorrência do vírus. Tratar-se-ia de uma nova condição que "em vez de se inserir no fulcro aberto pela conduta anterior, provoca um novo nexo de causalidade" (BITENCOURT, 2020, p.724).

O que se dessume, portanto, é que o evento morte gerado pela contaminação do vírus da COVID-19, sem analisar as peculiaridades de determinado caso concreto, não pode ser tido como um evento natural decorrente de disparos de arma de fogo. Há uma ruptura do nexo causal. A conduta do agente infrator não gerou, efetivamente, o resultado morte.

A contaminação pelo vírus da COVID-19 é a causa efetiva do resultado, tratando-se de claro evento imprevisível (em regra), o que acaba por excluir o nexo causal entre a empreitada delituosa (primeira causa) e o resultado morte (os disparos de arma de fogo não foram suficientes para levar a vítima a óbito). O agente, caso tenha atuado imbuído de animus necandi, responderá apenas pelos atos praticados anteriormente, isto é, pelo delito de homicídio, porém na modalidade tentada.

Mesmo que os disparos de arma de fogo tenham sido o motivo que levou a vítima ao hospital, o agente infrator não poderá responder pelo resultado mais gravoso (morte), visto que decorrente de evento fora de seu alcance ou, ainda, da possibilidade de previsão. São vários fatores que podem retirar tal previsibilidade, como o fato de o hospital não atender pacientes contaminados pela COVID-19, a vítima já ter desenvolvido anticorpos por uma contaminação anterior (o que geraria maior resistência), a vítima possuir uma maior resistência, por outras razões, à contaminação (citando-se a vacinação como exemplo), entre outros fatores que poderiam evitar o consequente falecimento.

Por óbvio que a situação pode se alterar a depender do contexto fático do local do delito, entretanto, não se pode assegurar, com clareza e como regra, que o agente infrator possui uma previsibilidade neste sentido quando da realização dos disparos de arma de fogo. A regra, ao menos aparente, é a imprevisibilidade.

Não se olvida que a tendência de alguns dos Tribunais Pátrios, ao menos os estaduais, é a de considerar que casos como infecção hospitalar ou, ainda, imperícia médica, seriam concausas relativamente supervenientes, que não romperiam o nexo causal, o que poderia afetar a lógica estabelecida na presente abordagem.

Contudo, os argumentos apresentados, ainda que específicos ao caso concreto, permitem que se estabeleça uma reflexão sobre aquelas questões, haja vista a evidência de que, em muitas dessas inexiste a continuidade causal do primeiro evento para a superveniência do resultado.

\section{Conclusão}

Ante o exposto, até pelas peculiaridades já apontadas, é possível trazer a lume o debate, a fim de que se averigue a 
previsibilidade (ou não) da contaminação por COVID-19 em casos de vítimas de disparo de arma de fogo.

A pergunta a ser respondida no caso concreto é, em síntese, a seguinte: a morte da vítima decorreu da soma entre a contaminação e os ferimentos causados pelos disparos de arma de fogo ou a contaminação, por si só, gerou o dito resultado? Configurando-se a última hipótese narrada se estaria diante de uma ruptura do nexo causal, respondendo o agente infrator apenas pelos atos anteriormente praticados.

As particularidades do caso se mostram relevantes. Tanto é que o Superior Tribunal de Justiça, em julgamento de litígio envolvendo infecção hospitalar, chegou à conclusão de que apenas "a instrução processual poderá demonstrar se a gravidade dos ferimentos propiciou ou não o surgimento da infecção. Isso porque tal demonstração afastaria a tese de que a concausa em exame rompeu o nexo causal" (STJ AgRg no REsp 1678232/SE, QUINTA TURMA, julgado em 24/10/2017, DJe 31/10/2017).

Em conclusão, até pela proposta reflexiva da abordagem, não se tem o entendimento apresentado como absoluto, mas sim uma perspectiva para o debate, a qual estabelece que a contaminação pela COVID-19, em ambiente hospitalar, em internação decorrente de ferimento de arma de fogo afasta o nexo causal (ao menos como regra, sem análise específica do caso concreto), de maneira que o agente deveria responder somente pela forma tentada do crime.

\section{Referências}

BITENCOURT, C.R. Tratado de Direito Penal - Volume I. Parte Geral (art. $1^{\circ}$ a 120). São Paulo: Saraiva, 2020.

CÓDIGO PENAL. Decreto-Lei n. ${ }^{\circ}$ 2.848, de 07 de dezembro de 1940. Rio de Janeiro. Disponível no sítio eletrônico: <http:// www.planalto.gov.br/ccivil_03/decreto-lei/del2848compilado. htm $>$. Acesso em 26 abr. $20 \overline{21}$

ESTEFAM, A.; GONÇALVES, V.E.R. Direito Penal Esquematizado. São Paulo: Saraiva, 2020.

NUCCI, G.S. Código Penal comentado. São Paulo: Revista dos Tribunais, 2019.

NUCCI, G.S. Manual de Direito Penal. Rio de Janeiro: Forense, 2020.

SUPERIOR TRIBUNAL DE JUSTIÇA. AgRg no REsp 1678232/ SE, QUINTA TURMA, julgado em 24/10/2017, DJe 31/10/2017. Disponível em: <www.stj.jus.br>. Acesso em 26 abr. 2021. 